\title{
Zasoby lokalne regionu pomorskiego i przykłady ich wykorzystania dla wzmocnienia rozwoju społeczno-gospodarczego obszarów wiejskich
}

\section{Local resources of the Pomeranian region and examples of their use for enhancing socio-economic development of rural areas}

\section{Gabriela CZAPIEWSKA}

Akademia Pomorska w Słupsku Instytut Geografii i Studiów Regionalnych ul. Partyzantów 27, 76-200 Słupsk gabrielaczapiewska@poczta.onet.pl

Zarys treści: W artykule omówiono rolę i znaczenie zasobów lokalnych dla rozwoju obszarów wiejskich Pomorza. Celem opracowania jest zaprezentowanie wybranych zasobów lokalnych regionu, stanowiących kulturowe dziedzictwo materialne, społeczne i przyrodnicze, ze szczególnym uwzględnieniem Kaszubszczyzny, a także możliwości ich wykorzystania w gospodarce i działalności społecznej wsi. W pierwszej części pracy ukazano zróżnicowanie przyrodniczo-krajobrazowe oraz kulturowe obszaru badawczego, zaś w drugiej specyfikę i bogactwo kulinarne regionu pomorskiego, produkty lokalne i tradycyjne. Atrakcyjność krajobrazu województwa pomorskiego jest duża, a to stanowi podstawę rozwoju osadnictwa i gospodarki turystycznej. Dobra jakość środowiska przyrodniczego i zrównoważone wykorzystanie jego zasobów jest podstawą trwałego rozwoju gospodarczego i społecznego regionu. Natężenie zabytkowej architektury wiejskiej, niespotykane nigdzie indziej w Europie, podkreśla unikalny charakter badanego obszaru i daje duże możliwości jego wykorzystania w kulturze i turystyce, wzmacniając tym samym jego potencjał. Lokalne i regionalne produkty żywnościowe cieszą się coraz większym uznaniem i zainteresowaniem konsumentów, co przyczynia się do wzmocnienia poczucia tożsamości regionalnej i lokalnej, a także rozwoju i promocji województwa pomorskiego.

Słowa kluczowe: zasoby lokalne, obszary wiejskie, rozwój społeczno-gospodarczy, Pomorze

\section{Wstęp}

Rozwój społeczno-gospodarczy regionu pomorskiego determinują czynniki wewnętrzne (endogeniczne) i zewnętrzne (egzogeniczne). Uwarunkowania zewnętrzne mają charakter makroekonomiczny (ogólny poziom rozwoju społeczno-ekonomicznego kraju, uwarunkowania historyczne, system gospodarki, polityka państwa i postęp techniczny). Z kolei uwarunkowania wewnętrzne tkwią w samym układzie lokalnym i wynikają niejako ze zlokalizowanych na danym obszarze zasobów, potencjału gospodarczego i korzystnych warunków środowiskowo-przestrzennych (Warczak 2015). Zdaniem S. Korenika (1999) 
są to wszelkie elementy mające znaczenie dla gospodarki danego obszaru, często o charakterze specyficznym, unikatowym, odpowiadającym tylko danemu układowi lokalnemu.

Ważnym czynnikiem endogenicznym rozwoju lokalnego są zasoby (ich dostępność, alokacja i produktywność). Zasoby lokalne oznaczają wszystko, co znajduje się w naszym otoczeniu, co kształtujemy, z czego korzystamy, co nam zapewnia utrzymanie, ułatwia życie i jest dla nas inspiracją. Zasoby te często towarzyszą nam od najmłodszych lat i stanowią potencjał, nawet gdy sobie tego nie uświadamiamy, bo wyrastając w danym środowisku, przywykliśmy do jego specyfiki. Wpisani jesteśmy w określoną obyczajowość, normy, wartości, zwyczaje i tradycje oczywiste dla całej społeczności, w której żyjemy. Zasoby lokalne to także wszystko, co odziedziczyliśmy po poprzednich pokoleniach, zbiorowa mądrość i wiedza, konieczność przekształcania przyrody, codzienna ciężka praca, praktyczne wykorzystywanie walorów natury (Spis rzeczy ważnych... 2012).

W artykule podjęto problematykę poświęconą roli i znaczeniu zasobów lokalnych dla rozwoju obszarów wiejskich Pomorza. Analizie poddano wybrane lokalne zasoby przyrodnicze i kulturowe obszarów wiejskich prezentowanego regionu oraz możliwości ich wykorzystania (m.in. do rozwoju działalności gospodarczej, przy podejmowaniu inicjatyw lokalnych, w celach edukacyjnych). Celem opracowania jest zaprezentowanie zasobów lokalnych regionu, stanowiących kulturowe dziedzictwo materialne, społeczne i przyrodnicze, ze szczególnym uwzględnieniem Kaszubszczyzny, a także przykłady możliwości wykorzystania tychże zasobów w gospodarce i działalności społecznej pomorskich wsi. W pierwszej części pracy, ukazano zróżnicowanie przyrodniczo-krajobrazowe oraz kulturowe badanego obszaru, zaś w drugiej jego specyfikę i bogactwo kulinarne oraz produkty lokalne i tradycyjne.

Zakres przestrzenny badań obejmował województwo pomorskie zajmujące powierzchnię 18310,34 km² (5,9\% powierzchni kraju), w tym 93,9\% stanowią obszary wiejskie. Położone w północnej części Polski, nad Morzem Bałtyckim jest jednym z trzech nadmorskich województw kraju. Swoim zasięgiem obejmuje trzy jednostki geograficzne: Pobrzeże Południowobałtyckie, Pojezierze Pomorskie i Żuławy. Administracyjnie region podzielony jest na 123 gminy (25 miejskich, 17 miejsko-wiejskich i 81 wiejskich) w 20 powiatach (16 ziemskich i 4 grodzkich: Gdańsk, Gdynia, Słupsk, Sopot). Na terenie województwa znajdują się 42 miasta i 2994 miejscowości wiejskie (1568 sołectw). Według danych GUS (na koniec 2014 r.) wsie badanego terenu zamieszkiwało 808791 osób, tj. 35,1\% ogółu mieszkańców województwa.

\section{Walory przyrodnicze regionu pomorskiego}

Zasoby środowiska przyrodniczego stanowią jeden z podstawowych elementów analitycznych w opisie i ocenie walorów każdego obszaru, będąc jednocześnie składową tzw. potencjału zasobowego, którego posiadanie, rodzaj i wielkość określają warunki rozwoju i zagospodarowania obszaru.

Województwo pomorskie należy do najbardziej zróżnicowanych przyrodniczo i krajobrazowo regionów Polski, o niezwykle urozmaiconej rzeźbie terenu pochodzenia polodowcowego. Do podstawowych cech przestrzeni badanego obszaru należą:

- nadmorskie położenie, z najdłuższym odcinkiem polskiej linii brzegowej, liczącym 316 km (łącznie z Zatoką Gdańską), co stanowi ponad 60\% linii brzegu morskiego kraju; 
- duże zróżnicowanie naturalnych warunków rozwoju - położenie nad Bałtykiem, depresje na Żuławach Wiślanych, najwyższe wzniesienie na Niżu Środkowoeuropejskim (Wieżyca 329 m n.p.m.), jedne z najlepszych gleb w Dolinie Wisły i bardzo słabe na pojezierzach;

- nadmorskie pasma rekreacyjno-osadnicze, które dominują w zagospodarowaniu strefy nadmorskiej;

- rozległa strefa pojezierna (liczne jeziora, duże kompleksy leśne, niski stopień przekształceń);

- system obszarów chronionych, obejmujący dwa parki narodowe: Słowiński i Bory Tucholskie, 9 parków krajobrazowych, 116 rezerwatów, 45 obszarów chronionego krajobrazu, a także wiele obiektów ochrony indywidualnej (2772 pomniki przyrody, 5 stanowisk dokumentacyjnych, 533 użytki ekologiczne). Obszary prawnie chronione zajmują blisko 1/3 powierzchni województwa (z wyłączeniem obszarów Natura 2000). Według danych GUS na koniec 2014 r. udział tych obszarów stanowił na badanym terenie $32,7 \%$ (ryc. 1). Najwięcej obszarów prawnie chronionych występuje w powiatach chojnickim (58,8\%), kościerskim (54,9\%), kartuskim (49,3\%) i gdańskim (49\%).

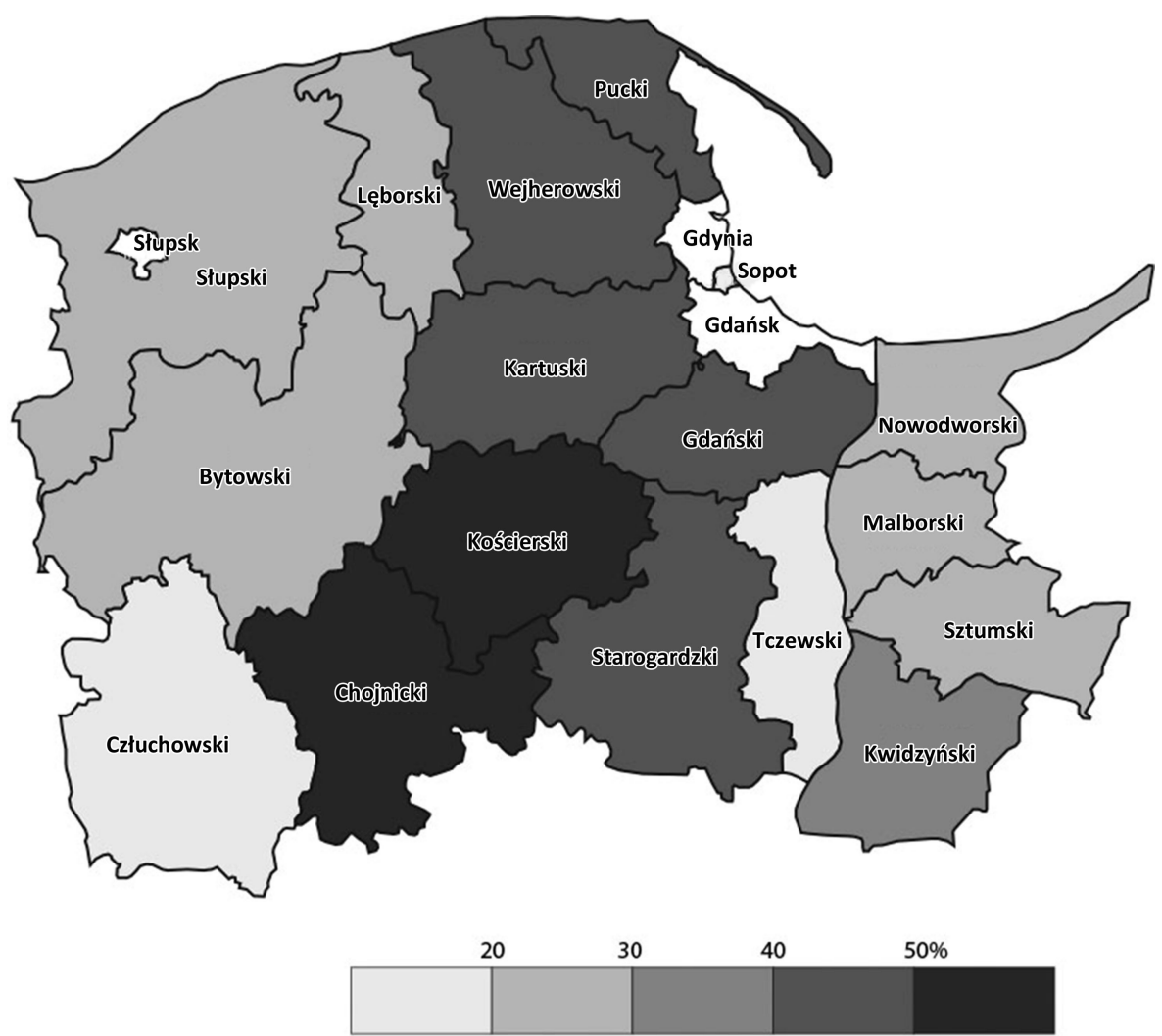

Ryc. 1. Udział procentowy obszarów prawnie chronionych w powierzchni ogółem na terenie województwa pomorskiego w $2014 \mathrm{r}$.

Źródło: Opracowanie na podstawie danych GUS (Bank Danych Lokalnych)

Percentage of areas protected by law in the total area of the Pomorskie Voivodeship in 2014

Source: Own study based on the Central Statistical Office (LDB) 
Na terenie województwa pomorskiego wyjątkowe są przybrzeżne akweny Bałtyku - Zatoka Pucka oraz Zalew Wiślany. Znaczenie ponadregionalne mają także kompleksy leśne oraz gęsta sieć rzek i jezior na rozległych obszarach pojeziernych i w strefie pobrzeży. Tereny te, determinując strukturę przyrodniczą Polski północnej, zostały uznane za międzynarodowe obszary węzłowe sieci ECONET. Na wszystkich tych obszarach kluczowe zasoby przyrodnicze stały się też elementami europejskiej sieci Natura 2000. Obszary specjalnej ochrony ptaków stanowiły na koniec 2014 r. 19,9\% powierzchni ogólnej, zaś specjalne obszary ochrony siedlisk zaledwie 9,7\%.

Wody powierzchniowe w województwie pomorskim w szczególny sposób kształtują cechy całego środowiska geograficznego. Jeziora tworzą skupiska o największej jeziorności w Polsce. Na Pojezierzu Kaszubskim wskaźnik ten dochodzi do 3,8\%, podczas gdy współczesną jeziorność całego Pojezierza Pomorskiego A. Choiński (2013) określa na 2,2\%. $\mathrm{Na}$ badanym terenie liczebnie dominują jeziora niewielkie lub tzw. oczka (o powierzchni poniżej 1 ha). Na Pojezierzu Kaszubskim jest ich około 8,5 tysiąca. Występują tu również unikalne i bardzo cenne przyrodniczo jeziora lobeliowe (obszar Borów Tucholskich, okolice Bytowa) oraz jeziora przybrzeżne (Łebsko, Gardno, Sarbsko). Największa liczba jezior lobeliowych charakteryzuje powiat bytowski (47), a także chojnicki (19), kartuski (18) i wejherowski (18). Czystość pomorskich jezior sprzyja rozwojowi turystyki. Doskonale nadają się one do uprawiania żeglarstwa, jak jeziora: Charzykowskie, Karsińskie, Raduńskie, Ostrzyckie, Jasień, Mausz, Kałębie, Żarnowieckie. Wiele miejscowości posiada dobrze rozbudowaną bazę turystyki wodnej.

Rzeki pojezierne wraz ze swymi dopływami tworzą tzw. kaszubski system hydrograficzny. Z centrum pojezierza spływają w kierunku Bałtyku (Wieprza, Słupia, Łupawa, Łeba, Reda), lub w kierunku Wisły (Radunia, Wierzyca, Wda i Brda). Ukształtowanie rzeźby terenu i sieci wodnej regionu ma znaczący wpływ na bogactwo siedlisk występujących na tym terenie, poczynając od piasków wydm nadmorskich, przez rozmaite typy torfów, gytii, gliny i piaski pojezierza, po żyzne czarne ziemie i mady żuławskie.

Jednym z ważniejszych zasobów województwa są lasy. Lesistość prezentowanego regionu wynosiła na koniec 2014 r. 36,3\% (trzecia lokata wśród województw w kraju, po lubuskim i podkarpackim), podczas gdy średnia krajowa - 29,4\%. Oprócz wskaźnika lesistości ważny jest także wskaźnik zasobów drzewnych w lasach, czyli wielkość grubizny brutto w korze. W województwie pomorskim szacuje się około $1860 \mathrm{mln} \mathrm{m}^{3}$ grubizny brutto. Powierzchnia lasów województwa stanowi 7,2\% całkowitej powierzchni lasów kraju. Największe zwarte kompleksy leśne znajdują się w jego zachodniej części, wśród nich Bory Tucholskie - jeden z większych kompleksów w Europie. Gospodarka leśna ma szczególne znaczenie w rozwoju województwa m.in. z uwagi na potencjał w zakresie tworzenia miejsc pracy na obszarach depresji gospodarczej. Dostępność surowca wpływa także na rozwój przedsiębiorstw drzewnych w regionie.

Zróżnicowanie elementów przyrody pozwala na wytyczanie licznych szlaków pieszych i kajakowych, a także tras rowerowych, których w regionie systematycznie przybywa. Sprzyjają temu także pozyskane przez samorządy i organizacje (lokalne grupy działania, organizacje pozarządowe) środki finansowe z budżetu Unii Europejskiej. Jednych z najbardziej atrakcyjnych obszarów w województwie, ale i w Polsce, pod względem przyrodniczym i krajobrazowym, jest powiat kościerski. Urozmaicona rzeźba terenu, sieć jezior rynnowych otoczonych lasami, czyste rzeki, bogactwo gatunków roślin i zwierząt powodują, że region ten, potocznie nazywany Szwajcarią Kaszubską, można zaliczyć do wyjątko- 
wych miejsc. Lasy w powiecie kościerskim zajmują 44\% jego powierzchni, zaś wody blisko 5\%. Duża część rzek i jezior położona jest wśród lasów, co znacznie podwyższa ich wartość wypoczynkową. Nie bez znaczenia jest także fakt, że prawie wszystkie jeziora, spośród ponad 200 występujących na terenie powiatu, objęte są gospodarką rybną. Na szczególną uwagę zasługuje, położony w całości na terenie powiatu, Wdzydzki Park Krajobrazowy o powierzchni 17857 ha, którego atrakcją jest zespół Jezior Wdzydzkich obejmujący obszar o łącznej powierzchni 1455,6 ha. Na terenie powiatu panują doskonałe warunki dla wędkarzy i myśliwych oraz do uprawiania turystyki pieszej i rowerowej, a także sportów wodnych - żeglarstwa, motorowodniactwa czy kajakarstwa.

\section{Zasoby kulturowe obszarów wiejskich województwa pomorskiego}

Na badanym obszarze, obok walorów przyrodniczo-krajobrazowych, istotną rolę odgrywają także zasoby kulturowe, związane na przede wszystkim z tradycją kaszubską. Znaczną część województwa pomorskiego zajmują Kaszuby, zasiedlone przez jedną z najliczniejszych w Polsce grup etnicznych, która zachowała do dziś swój język i obyczaje. Większość Kaszubów posiada podwójną identyfikację - narodową polską i etniczną kaszubską (Latoszek 1990). Według kryteriów etnicznych, przyjętych przez J. Mordawskiego ${ }^{1}$ (1999), terytorium Kaszub obejmuje 43 gminy województwa pomorskiego, zlokalizowane na terenie 8 powiatów, o łącznej powierzchni 6200 km² (ryc. 2). Wyniki spisu powszechnego, przeprowadzonego w kraju w 2011 r. dowiodły, iż narodowość kaszubską zadeklarowało wówczas 233 tys. osób, z czego 108140 osób posługuje się językiem kaszubskim w kontaktach domowych.

Kaszubszczyzna, szczególnie w ostatnich czasach, pojawia się w nowych sferach, które sprzyjają jej bezpośredniemu dowartościowaniu. Język kaszubski ma uregulowany statut prawny ustawą z dnia 6 stycznia 2005 r. o mniejszościach narodowych i etnicznych oraz o języku regionalnym. W związku z ministerialnym przyzwoleniem prowadzenia edukacji etnicznej w szkole, jak również wytyczeniem dla niej ram programowych, na Kaszubach ożywił się ruch związany z wprowadzaniem nauki języka kaszubskiego. Ministerstwo Edukacji zatwierdziło w 1999 r. programy nauczania w szkołach oraz wydało podręczniki w tym języku, a w kościołach odprawiane są nabożeństwa po kaszubsku. Stopniowo zwiększa się również liczba dzieci uczących się tego etnodialektu w szkołach. Ponadto w 2006 r. rozpoczęła działalność Rada Języka Kaszubskiego - organ zajmujący się między innymi regulacją języka kaszubskiego oraz upowszechnianiem i promowaniem wiedzy o nim.

Od stuleci Kaszubi (autochtoniczni Pomorzanie) pielęgnują swoją odrębność kulturową (Czapiewska 2014). Najznamienitszą tradycją kaszubską jest siedmiobarwny haft, charakterystyczny z powodu występujących w nim motywów (tulipany, owoce granatu, margerytki, róże i serca w kratę). Na Kaszubach ma on długą tradycję, która sięga okoto 1209 r. Obecnie obok haftu kaszubskiego jedną z najpopularniejszych dziedzin sztuki ludowej na Kaszubach jest plecionkarstwo. Przeżywa ono renesans swojego istnienia, gdyż stało się popularne nawet w rejonach Kaszub, gdzie w przeszłości uprawiane było sporadycznie. Plecionkarstwo to sztuka, którą wykonują Kaszubi nieprzerwanie od czasów średniowiecza. Ze względu na łatwy dostęp do materiałów tworzyli oni niegdyś różnego

\footnotetext{
${ }^{1}$ W obręb Kaszub zaliczono te jednostki terytorialne, w których Kaszubi stanowią co najmniej 1/3 populacji, jak i aglomeracje zamieszkiwane przez dużą liczbę ludności tej grupy etnicznej.
} 
rodzaju przedmioty codziennego użytku. Najczęściej wykorzystywanym surowcem była wiklina i słoma, ale wyplatano również z korzeni sosny, świerku oraz jałowca. Możliwość nawiązywania do tradycyjnych wyrobów plecionkarskich wykonywanych przed laty, ale także kreowania niemal dowolnych form przedmiotów o ciekawych splotach, z różnorodnych, powszechnie dostępnych naturalnych surowców wpisanych w krajobraz najbliższego otoczenia, wskazuje na znaczny potencjał rynkowy wyrobów plecionkarskich, używanych m.in jako opakowania na owoce. Produkcja wyrobów z drewna, słomy, korka i wikliny w regionie systematycznie wzrasta, czego dowodem jest wartość produkcji sprzedanej. Według danych GUS² na koniec 2014 r. wynosiła ona 2302,1 mln zł i wzrosła w stosunku do roku poprzedniego o 12,3\%. Warto dodać iż w okresie 2012-2013 odnotowano aż 34,5\% wzrost. Jednocześnie widoczna jest w regionie tendencja wzrostowa, jeśli chodzi o przeciętne zatrudnienie osób w przedsiębiorstwach zajmujących się tego typu przetwórstwem (o 7,4\% w latach 2013-2014).

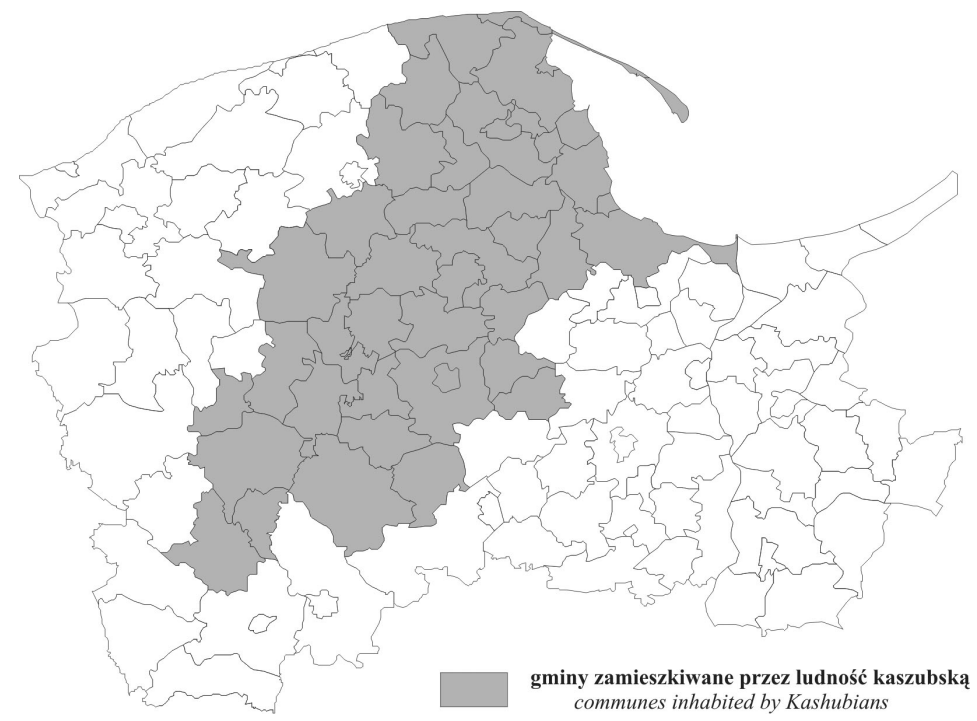

Ryc. 2. Zasięg terytorialny Kaszub

Źródło: Opracowanie na podstawie: J. Mordawski (1999).

Territorial range of Kashubia

Source: Own study based on: J. Mordawski (1999).

Powszechnym elementem tradycji jest także ekspozycja wielokolorowych i czarnych wyrobów ceramicznych pochodzących z warsztatów Meisnera w Kartuzach i Necla w Chmielnie. Garncarstwo to jedno z najstarszych i najpowszechniejszych dawnych rzemiosł. Współcześnie uprawiają go jedynie osoby silnie związane z tradycją, często wynoszące technikę garncarstwa z rodzinnego domu lub pasjonaci, którzy na licznych warsztatach uczą się rzemiosła. Przykładem jest rodzinny zakład Neclów w Chmielnie, gdzie dziewiąte już pokolenie zajmuje się podtrzymywaniem wieloletnich tradycji rodzinnych, zajmując się ręcznym wyrobem ceramiki ozdobnej w oparciu o starą technologię i wzbogacone wzornictwo. Ceramika ta robiona jest przede wszystkim z myślą o odbiorcy miejskim.

\footnotetext{
2 Przemyst i działalność innowacyjna w województwie pomorskim w 2014 roku, 2015, Opracowania sygnalne, Urząd Statystyczny w Gdańsku, Gdańsk
} 
W przeszłości dla ludzi żyjących na wsi tradycyjne rzemiosła były codziennością, sposobem na życie oraz tradycją przekazywaną z pokolenia na pokolenie. Obecnie zauważyć można znaczący spadek liczby aktywnych twórców³ ${ }^{3}$ którzy wciąż czynnie prowadzą swoją działalność artystyczną. Stowarzyszenie Twórców Ludowych zrzesza obecnie 2161 autentycznych twórców ${ }^{4}$, najwięcej w województwach: lubelskim (580) i małopolskim (542) 5 . Twórczość ludowa ma charakter regionalny, a województwo pomorskie skupia twórców ludowych o wysokim poziomie autentyczności, czego niewątpliwą zasługą są nadal żywotne regiony etnograficzne - Kaszuby i Kociewie - z zachowaną, kultywowaną i wspieraną kulturą tradycyjną. W województwie pomorskim w 2013 r., tradycję rzemiosła artystycznego kultywowało 170 aktywnych twórców ludowych, co uplasowało region na dziewiątym miejscu w kraju.

Równie bogata jak tradycja materialna, jest tradycja obyczajowa regionu kaszubskiego, związana m.in. z muzyką kaszubską czy tańcami. W dawnej społeczności wiejskiej bieg życia wyznaczały normy społeczne i wartości uznawane przez jej członków, które miały odzwierciedlenie w zwyczajach oraz obrzędach dorocznych i rodzinnych. Przykładem cyklicznie odbywających się imprez jest Międzynarodowy Festiwal Folklorystyczny, Zjazd Kaszubów, także o międzynarodowym charakterze czy Truskawkobranie - impreza nierozerwalnie związana z tradycją truskawkowych dożynek.

Ważny jest też fakt, iż na badanym terenie funkcjonują instytucje, które pielęgnują kulturę regionu. Wśród nich wymienić należy: Muzeum Kaszubskie im. Franciszka Tredera w Kartuzach, Muzeum Piśmiennictwa i Muzyki Kaszubsko-Pomorskiej w Wejherowie czy Muzeum Zachodniokaszubskie w Bytowie. Ponadto na obszarach wiejskich województwa pomorskiego zlokalizowanych jest 7 parków etnograficznych i 2 parki kulturowe (tab. 1). Dwa parki kulturowe funkcjonują także na obszarach miejskich - Park Kulturowy „Klasztorne Stawy” w Słupsku i Park Kulturowy Fortyfikacji Miejskich „Twierdza Gdańsk” w Gdańsku.

Tabela 1. Parki kulturowe i etnograficzne na obszarach wiejskich województwa pomorskiego

\begin{tabular}{|c|c|c|c|}
\hline Wyszczególnienie & Wieś & Gmina & Powiat \\
\hline \multicolumn{4}{|c|}{ Parki kulturowe } \\
\hline $\begin{array}{l}\text { Park Kulturowy Ośmiu Błogosławieństw } \\
\text { Park Kulturowy „Osada Łowców Fok” }\end{array}$ & $\begin{array}{l}\text { Sierakowice } \\
\text { Rzucewo }\end{array}$ & $\begin{array}{l}\text { Sierakowice } \\
\text { Puck }\end{array}$ & $\begin{array}{l}\text { kartuski } \\
\text { pucki }\end{array}$ \\
\hline \multicolumn{4}{|c|}{ Parki etnograficzne } \\
\hline $\begin{array}{l}\text { Muzeum Wsi Słowińskiej } \\
\text { muzeum Kultury Ludowej Pomorza } \\
\text { zagroda Gburska i Rybacka } \\
\text { Muzeum Budownictwa Regionalnego } \\
\text { Skansen Kaszubski } \\
\text { Skansen - Centrum Edukacji i Promocji Regionu } \\
\text { Kaszubski Park Etnograficzny }\end{array}$ & $\begin{array}{l}\text { Kluki } \\
\text { Swołowo } \\
\text { Nadole } \\
\text { Silno } \\
\text { Sominy } \\
\text { Szymbark } \\
\text { Wdzydze Kiszewskie }\end{array}$ & $\begin{array}{l}\text { Smołdzino } \\
\text { Słupsk } \\
\text { Gniewino } \\
\text { Chojnice } \\
\text { Studzienice } \\
\text { Stężyca } \\
\text { Kościerzyna }\end{array}$ & $\begin{array}{l}\text { słupski } \\
\text { słupski } \\
\text { wejherowski } \\
\text { chojnicki } \\
\text { bytowski } \\
\text { kartuski } \\
\text { kościerski }\end{array}$ \\
\hline
\end{tabular}

Źródło: Opracowanie własne na podstawie danych Narodowego Instytutu Dziedzictwa; www.skanseny.prv.pl (dostęp z dnia 18.05.2015)

3 Twórcą ludowym uznawana jest osoba działająca w kręgu społeczności wiejskiej, tworząca dzieła, charakteryzujące się wysokim poziomem artystycznym oraz oryginalnością, a swe umiejętności nabyła poprzez obserwację lub w sposób bezpośredni, ale nie posiada profesjonalnego wykształcenia w danej dziedzinie.

4 www.zgstl.pl (dostęp z dnia 20.06.2016)

${ }_{5}^{5}$ Raport statystyczny - twórcy ludowi i ginqce zawody (wg bazy danych STL za 2013 rok), www.cbos.pl (dostęp z dnia 11.05.2015) 
Do sztandarowych obiektów należy najstarsze na ziemiach polskich muzeum na wolnym powietrzu - Kaszubski Park Etnograficzny im. Teodory i Izydora Gulgowskich we Wdzydzach Kiszewskich. Zgromadzono w nim ponad 50 obiektów architektury ludowej z obszaru Kaszub i Kociewia (chałupy, dwory, szkoła, kościół, kuźnia, karczmy, wiatraki, budynki gospodarcze i warsztaty rzemieślnicze). Podziwiać tam można sztukę garncarstwa, bursztyniarstwa, ludowe hafty, niezwykłe atrakcje sztuki i rzemiosła. Wiernie odtworzone wnętrza wraz z autentycznym wyposażeniem, czasowo uruchamiane urządzenia gospodarcze i przemysłowe nadają temu miejscu niezwykły klimat, spotęgowany malowniczym położeniem i walorami otaczającej przyrody. Skansen położony na atrakcyjnym turystycznie terenie, nad kompleksem Jezior Wdzydzkich, niewątpliwie łączy walory krajobrazowe, edukacyjne oraz rekreacyjne. W 2006 r. Muzeum we Wdzydzach Kiszewskich obchodziło 100-lecie istnienia. Corocznie odwiedza je blisko 70 tys. osób, z których znaczną część stanowią dzieci i młodzież. Do odwiedzania tego miejsca zachęca turystów w każdym wieku bogata oferta Muzeum - całoroczny program imprez na czele z Jarmarkiem Wdzydzkim

Kultura kaszubska stanowi trwałą podwalinę kreowania tożsamości kulturowej regionu i w istotny sposób wzbogaca współczesną wielokulturowość badanego obszaru (Olbracht-Prondzyński 2007). Na terenie województwa pomorskiego funkcjonuje także najnowocześniejsza placówka typu skansenowskiego w Polsce - Muzeum Kultury Ludowej Pomorza w Swołowie. Oferuje możliwość zwiedzania 13 zrewitalizowanych zabytkowych obiektów budownictwa wiejskiego wzniesionych w konstrukcji szkieletowej. Szachownica budynków na stałe wpisała się w krajobraz wsi, dlatego Swołowo nazywane jest stolicą „Krainy w Kratę”. Odbudowane i wyremontowane XIX-wieczne zabytki pełnią funkcję wystawienniczą i kulturalną. W dwóch stodołach oraz oborze urządzono multimedialne wystawy etnograficzne obrazujące historię i kulturę wiejską Pomorza. W muzeum realizowany jest bogaty program edukacyjny dla dzieci i młodzieży (m.in. lekcje i warsztaty związane tematycznie z obrzędowością i życiem codziennym na dawnej pomorskiej wsi). Ponadto w skansenie odbywają się cykliczne imprezy, z których najpopularniejsze wśród turystów to „Szparagowe Święto”, „Dziecięca Zagroda” czy impreza kulinarna „Na św. Marcina najlepsza pomorska gęsina”, przyciągająca smakoszy gęsiego mięsa z całego kraju. Unikalne walory architektoniczne i przestrzenne wsi sprawiły, że Swołowo otrzymało tytuł Europejskiej Wsi Dziedzictwa Kulturowego.

Kulturę, tradycje regionu oraz jego zasoby przyrodnicze pielęgnują także lokalne grupy działania, których na terenie województwa pomorskiego funkcjonuje 16 (tab. 2). Obszar każdej pomorskiej lokalnej grupy działania jest unikatowy, interesujący i oferuje wiele atrakcji. Przykładowo na obszarze LGD Partnerstwo Dorzecze Słupi (największej w regionie pod względem zajmowanej powierzchni oraz liczby gmin) znajduje się jeden z głównych produktów markowych pomorskiej wsi - „Kraina w kratę”. LGD wspiera wszelkie projekty sprzyjające wykorzystaniu lokalnych zasobów dla rozwoju turystycznego obszaru oraz aktywizacji społecznej i kulturalnej mieszkańców. Najciekawsze produkty turystyczne obszaru są promowane pod wspólną marką regionalną Zielone Serce Pomorza.

Generalnie wszystkie lokalne grupy działania, funkcjonujące na terenie województwa pomorskiego, kładą główny akcent na wykorzystanie cennych zasobów dla rozwoju turystycznego, przy jednoczesnym zachowaniu i promocji dziedzictwa kulturowego. Tradycje

${ }^{6}$ www.muzeum-wdzydze.gda.pl (dostęp z dnia 1.04.2016), www.na-kaszuby.pl (dostęp z dnia 1.04.2016) 
oraz bogatą kulturę Kaszubów propagują lokalne grupy działania: Bursztynowy Pasaż, Stolem, Kaszubska Droga oraz Stowarzyszenie Turystyczne Kaszuby (90\% ogółu mieszkańców LGD stanowi ludność kaszubska). Natomiast na promowaniu dziedzictwa kulturowego Kociewia koncentrują swoje działania LGD Chata Kociewia i LGD Wstęga Kociewia. Kultywowanie dziedzictwa dawnych osadników części żuławskiej - menonitów, którzy pozostawili po sobie bogatą kulturę materialną, zadbane wioski i liczne cmentarze, wynika ze strategii lokalnych grup działania Trzy Krajobrazy oraz Żuławy i Mierzeja. Podkreślić należy, że coraz więcej turystów zainteresowanych jest bowiem regionalizmami i poszukiwaniem lokalnych odmienności.

Tabela 2. Lokalne grupy działania w województwie pomorskim

\begin{tabular}{|c|c|c|c|c|}
\hline Lp. & $\begin{array}{c}\text { Nazwa } \\
\text { LGD }\end{array}$ & $\begin{array}{l}\text { Liczba gmin obję- } \\
\text { tych działaniem } \\
\text { LGD }\end{array}$ & $\begin{array}{l}\text { Powierzchnia obję- } \\
\text { ta działaniem LGD } \\
\text { (w km²) }\end{array}$ & $\begin{array}{l}\text { Siedziba } \\
\text { LGD }\end{array}$ \\
\hline 1. & Bursztynowy Pasaż & 6 & 1073 & Krokowa \\
\hline 2. & Chata Kociewia & 14 & 1754 & Nowa Wieś Rzeczna \\
\hline 3. & Kaszubska Droga & 5 & 817 & Przetoczyno \\
\hline 4. & Kraina Dolnego Powiśla & 5 & 681 & Dzierzgoń \\
\hline 5. & Małe Morze & 4 & 321 & Puck \\
\hline 6. & Naszyjnik Północy & 6 & 1575 & Debrzno \\
\hline 7. & Partnerstwo Dorzecze Słupi & 17 & 3673 & Dębnica Kaszubska \\
\hline 8. & Powiślańska & 5 & 813 & Kwidzyn \\
\hline 9. & Sandry Brdy & 5 & 1653 & Chojnice \\
\hline 10. & Spichlerz Żuławski & 5 & 477 & Lichnowy \\
\hline 11. & Stowarzyszenie Turystyczne Kaszuby & 9 & 1250 & Kartuzy \\
\hline 12. & Stolem & 5 & 827 & Lipusz \\
\hline 13. & Trzy Krajobrazy & 6 & 648 & Pruszcz Gdański \\
\hline 14. & Wrzeciono & 2 & 692 & Miastko \\
\hline 15. & Wstęga Kociewia & 5 & 675 & Morzeszczyn \\
\hline 16. & Żuławy i Mierzeja & 5 & 651 & Nowy Dwór Gdański \\
\hline
\end{tabular}

Źródło: opracowanie na podstawie bazy danych Krajowej Sieci Obszarów Wiejskich, www.ksow.pl (dostęp z dnia 1.04.2016)

\section{Produkty regionalne i tradycyjne jako element promocji i rozwoju obszarów wiejskich}

Wpływ na rodzaj i jakość specjałów w regionie pomorskim ma położenie geograficzne i dostępność różnorodnych płodów rolnych. Znaczący jest również potencjał produkcyjny gospodarstw rolnych, gdzie stosowane są tradycyjne metody uprawy bez środków chemicznych i mineralnego, intensywnego nawożenia. Zdrowa żywność wytwarzana jest w gospodarstwach ekologicznych, których liczba na badanym terenie systematycznie wzrasta. W 2014 r. w województwie pomorskim funkcjonowało 847 gospodarstw ekologicznych, podczas gdy w 2004 r. jedynie 66 rolników prowadziło produkcję metodami ekologicznymi (Czapiewska 2016). 
Kuchnia pomorska to kuchnia subregionów: Kaszub, Kociewia, Żuław i Powiśla. Odzwierciedleniem specyfiki i bogactwa kulinarnego województwa jest lista produktów tradycyjnych, prowadzona przez Ministra Rolnictwa i Rozwoju Wsi. Na ministerialną listę zostały dotychczas wpisane 174 potrawy przyrządzane w regionie według starych receptur i tradycją związane z Pomorzem. Zarejestrowane produkty są częścią historii i kultury, z której wywodzą się Pomorzanie. Badany region, pod względem liczby zarejestrowanych produktów tradycyjnych, znajduje się na drugim miejscu w kraju, po województwie podkarpackim (207 produktów). Zatem 11,2\% wpisanych na listę produktów tradycyjnych pochodzi z Pomorza. Biorąc pod uwagę kategorie poszczególnych produktów, województwo pomorskie zajmuje pierwszą lokatę, jeśli chodzi o produkty rybołówstwa (17 produktów), stanowiąc 28,3\% wszystkich produktów tej kategorii wpisanych na listę produktów tradycyjnych.

Tabela 3. Produkty tradycyjne i regionalne Pomorza zarejestrowane na krajowej liście w latach 2006-2016

\begin{tabular}{|c|c|c|c|c|c|c|c|c|c|c|c|c|}
\hline \multirow[b]{2}{*}{ Kategorie produktów } & \multicolumn{11}{|c|}{ Lata } & \multirow{2}{*}{$\frac{\varepsilon}{\frac{\varepsilon}{d 0}}$} \\
\hline & ஜ్̊ & 옹 & \&̊유 & 옹 & 응 & 공 & 공 & 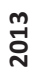 & 离 & ํㅗㅇ & 엉 & \\
\hline Mleczne & - & - & 2 & - & - & 1 & - & - & - & - & - & 3 \\
\hline Mięsne & 2 & 2 & 2 & 7 & 1 & 5 & 1 & - & 3 & 4 & - & 27 \\
\hline Rybołówstwa & 3 & 2 & 1 & 1 & - & 5 & 1 & - & 4 & - & - & 17 \\
\hline Warzywa i owoce & 2 & 1 & 4 & 2 & - & 1 & 1 & - & 4 & - & - & 15 \\
\hline Piekarnicze i cukiernicze & 6 & 4 & 6 & 1 & - & 2 & 2 & 1 & 6 & 1 & - & 29 \\
\hline Oleje i tłuszcze & - & 2 & - & - & - & - & - & - & 1 & 2 & - & 5 \\
\hline Miody & - & 2 & - & 1 & - & - & - & - & - & - & - & 3 \\
\hline Dania gotowe i potrawy & 12 & 10 & 10 & 5 & - & 5 & 1 & - & 4 & 5 & - & 52 \\
\hline Napoje & 5 & 1 & 6 & 1 & - & 1 & 1 & 1 & - & 1 & 1 & 18 \\
\hline Inne & - & 2 & - & - & - & 1 & - & - & - & 2 & - & 5 \\
\hline OGÓłEM & 30 & 26 & 31 & 18 & 1 & 21 & 7 & 2 & 22 & 15 & 1 & 174 \\
\hline
\end{tabular}

Źródło: Opracowanie na podstawie listy produktów tradycyjnych MRiRW (według stanu na dzień 30.04.2016r), www.minrol.gov.pl (dostęp z dnia 1.04.2016)

W województwie pomorskim w latach 2006-2016 najwięcej produktów regionalnych zarejestrowanych zostało na liście w kategoriach: dania gotowe i potrawy (52 produkty, tj. 29,9\% produktów ogółem w regonie), piekarnicze i cukiernicze (29) oraz mięsne (27). Wśród dań dominują potrawy z ryb, ziemniaków, grzybów oraz zupy i dania mięsne.

\footnotetext{
${ }^{7}$ Lista Produktów Tradycyjnych została utworzona na mocy ustawy z 17 grudnia 2004 r. o rejestracji i ochronie nazw i oznaczeń produktów rolnych i środków spożywczych oraz o produktach tradycyjnych (DzU z 2005 r. nr 10, poz. 68, z późn. zm.). Listę prowadzi Minister Rolnictwa i Rozwoju Wsi we współpracy z marszałkami województw. W Polsce na listę produktów tradycyjnych wpisane zostały dotychczas 1551 produkty rolne, środki spożywcze i napoje spirytusowe, których jakość lub wyjątkowe cechy i właściwości wynikają ze stosowania tradycyjnych metod produkcji, za które uważa się metody wykorzystywane od co najmniej 25 lat (okres ten odnosi się do produktu, a nie do konkretnego producenta); będące elementem dziedzictwa kulturowego regionu, w którym są wytwarzane; będące elementem tożsamości społeczności lokalnej; klasyfikujące się w dziesięciu kategoriach: 1. sery i inne produkty mleczne, 2. mięso świeże oraz produkty mięsne, 3. przetwory rybołówstwa, w tym ryby, 4. warzywa i owoce (przetworzone i nie), 5. wyroby piekarnicze i cukiernicze, 6. oleje i tłuszcze (masło, margaryna olej itp.), 7. miody, 8. gotowe dania i potrawy, 9. napoje (alkoholowe i bezalkoholowe), 10. inne produkty, np. grzyby, www.minrol.gov.pl (dostęp z dnia 1.04.2016)
} 
Największą liczbę produktów regionalnych zarejestrowano na krajowej liście w 2006 r. i 2008 r. - odpowiednio 30 i 31 (tab. 3). Pierwszym zarejestrowanym produktem regionalnym w województwie pomorskim była okrasa z gęsiny (22.02.2006 r.), natomiast ostatnim dotychczas wpisanym na listę produktem jest nalewka ze świętojonki (19.01.2016 r.), czyli czerwonej porzeczki.

Według Kuchni Pomorskiej (Ditrich i Słubik 1998) za najbardziej specyficzną cechę kuchni kaszubsko-pomorskiej i gdańskiej uważa się powszechne bogactwo ryb i potraw rybnych zarówno z ryb morskich, jak i słodkowodnych, które żyją w kaszubskich jeziorach. Potrawy z ryb, głównie dorsza, węgorza i śledzia, przyrządzane na wiele różnych sposobów, w całym regionie pomorskim są jednym z podstawowych dań, zróżnicowanych w zależności od lokalnych tradycji oraz sposobu ich pozyskiwania. Pomorze to też jeden z najbardziej grzybodajnych regionów w Polsce. Liczne odmiany grzybów zarówno niegdyś, jak i obecnie przyrządzane są w kuchni pomorskiej na różne sposoby (marynowane w occie, duszone, gotowane, smażone, przygotowywane są z nich sosy i zupy, nadzienia do pierogów, dodatek do jajecznicy). Jednak najpopularniejszym sposobem ich przechowywania jest suszenie. Z kolei w kuchni kociewskiej grzyby bardzo często były podawane jako potrawa podstawowa.

Badany region znany jest także z obfitości owoców leśnych, które od wieków stanowiły dodatek do przyrządzanych potraw (borówka, czarna jagoda). Owocem bardzo cenionym na Kaszubach jest żurawina, obficie występująca w pomorskich lasach i na torfowiskach. Owoce leśne stanowią także doskonałą bazę do wytwarzania nalewek. Przykładowo na terenie gminy Choczewo wytwarza się nalewkę jagodową, której receptury, jak dowodzą badania etnograficzne, sięgają okresu przedwojennego. Nalewka malinówka z okolic Kartuz wytwarzana jest z malin leśnych, które porastają stoki Wzgórz Szymbarskich. W 2015 r. została wpisana na listę produktów regionalnych. Obok nalewek w regionie wytwarzane są także miody pitne, jak np. kaszubski miód pitny (od 2008 r. na krajowej liście). Nalewki powstające na bazie owoców, ziół i miodów są charakterystyczne dla pomorskiej kuchni staropolskiej.

Na Kaszubach ze względu na lekkie gleby uprawiało się ziemniaki, które następnie spożywano pod wieloma postaciami klusek, kopytek, placków lub podsmażone albo jako dodatek do zupy (Niemiec 2004). W kuchni kaszubskiej wśród potraw ziemniaczanych oryginalna jest kiszka kaszubska czy plińce kaszubskie, zaś na Kociewiu tradycyjnym daniem jest szandar kociewski. Popularny jest też kaszubski sernik z ziemniakami czy kaszubski chleb żytni na ziemniakach, będący ważnym elementem tożsamości i dziedzictwa kulturowego Kaszub. W pomorskiej kuchni ważną rolę odgrywały niegdyś zupy, jak żur, zupa z żółtej brukwi i prostym wywarem z ziemniaków z zacierkami zwanym zupą zagraj lub dziadowską zupą. Bardzo popularnym warzywem uprawianym w gospodarstwach kaszubskich była kapusta, z której przygotowywano zupy (np. parzybrodę, kapuśniak) oraz dania główne (np. kapustę duszoną na wędzonce).

Województwo pomorskie od wieków zamieszkiwały różne grupy narodowe, etniczne i regionalne, co miało duży wpływ na różnorodność potraw mięsnych tu przygotowywanych. Mięso na przetwory często pochodziło z konkretnej rasy zwierząt specjalnie hodowanych w warunkach regionalnych, zaś tradycja ich wyrobów przekazywana była z pokolenia na pokolenie. Prezentowany region wyróżniał się bogactwem i różnorodnością kulinarną, na którą oddziaływały nowinki z krajów Europy, docierające przez Bałtyk. Dzięki temu wpływowi subregiony wzbogacały rodzime tradycje, nadając im szczególny 
charakter. Przykładem mogą być liczne wyroby piekarnicze i cukiernicze, w tym tradycyjnie wypiekane w kamionkach i na zakwasie pieczywo oraz charakterystyczne ruchanki, fefernuski kociewskie i kuchy (m.in. kaszubski kuch marchwiowy, młodzowy kuch z kruszonką).

Powodem do dumy województwa pomorskiego jest truskawka kaszubska (kaszëbskô malëna), której nazwa została zarejestrowana jako Chronione Oznaczenie Geograficzne w Unii Europejskiej ${ }^{8}$. Jest ona trzynastym polskim produktem objętym ochroną przez prawo unijne, a pierwszym w województwie pomorskim. Renomy, jaką teraz posiada truskawka kaszubska, nie dałoby się uzyskać gdyby nie warunki klimatyczne, które sprzyjają uprawom na tym terenie, zwłaszcza w powiatach kartuskim, kościerskim, bytowskim i wejherowskim.

Za sprawą Listy Produktów Tradycyjnych ochronie podlega także dziedzictwo kulturowe wsi, co w dużym stopniu przyczynia się do zwiększenia atrakcyjności terenów wiejskich oraz rozwoju agroturystyki i turystyki wiejskiej. Lokalne surowce rolne i środki spożywcze zastosowane do starych receptur na dania regionalne, od lat oferowane turystom w gospodarstwach agroturystycznych, coraz częściej są wykorzystywane przez restauratorów i przetwórców żywności, czego przykładem może być szlak, jaki tworzą członkowie Sieci Dziedzictwa Kulinarnego - Pomorskie (restauracje, gospodarstwa agroturystyczne, lokalni producenci i przetwórcy). Miejsca oznaczone logiem z białą kucharską czapką są wyjątkowe, gdyż nie tylko oferują lokalne i regionalne produkty i potrawy, ale także promują zwyczaje i kulturę regionu, zwłaszcza jego historię, ludową muzykę i rękodzieło. Ciekawą propozycją dla turystów, jak i smakoszy jakościowych kulinariów jest Szlak „Gdańsk - Pomorskie Culinarny Prestige". Tworzą go restauracje z całego regionu pomorskiego, gotujące w zgodzie z przyjętą filozofią slow food. Serwują dania autorskie, bazując na regionalnych produktach, na najwyższym europejskim poziomie. Szlak kulinarny to nie tylko oferta restauracyjna, ale również szereg wydarzeń kulinarnych opartych tematycznie o regionalne specjały, dopełniające tym samym ofertę kulinarną regionu. Warto tu wspomnieć o takich wydarzeniach jak: Noc Restauracji, Sopot od kuchni, czyli Slow Food Festival, Święto Szparagów, Chmielaton, Festiwal Żurawiny, Truskawkobranie, Pomorska Gęsina na św. Marcina czy Festiwal Pomuchla9 ${ }^{9}$ Koordynatorem projektu jest Pomorska Regionalna Organizacja Turystyczna.

Istotnym elementem promocji kuchni regionu jest również, organizowany od 2001 r., ogólnopolski konkurs na najlepszy regionalny i lokalny produkt żywnościowy oraz na najlepsze danie czy potrawę regionalną i lokalną „Nasze Kulinarne Dziedzictwo - Smaki Regionów". Głównym celem konkursu jest identyfikacja i promocja produktów regionalnych, osadzonych głęboko w polskiej tradycji i od lat wytwarzanych tymi samymi metodami i według tych samych receptur. Konkurs miał dostarczyć konsumentom i handlowcom informacji o jakości i walorach tradycyjnej, regionalnej i lokalnej żywności, a także wskazać alternatywę w stosunku do masowo sprzedawanej żywności, wytwarzanej przemysłowymi metodami. Ideą konkursu jest też zachęcanie mieszkańców obszarów wiejskich, zwłaszcza tych o niekorzystnych warunkach gospodarowania, do poszukiwania alternatywnych źródeł dochodu. Nagrodą najwyższej rangi w tym konkursie jest statuetka „Perła”, przyznawana przez Krajową Kapitułę Konkursu. Na początku przyznawano nagrody jedynie w kategorii produkt, natomiast w 2008 r. rozszerzono formułę konkursu, wpro-

\footnotetext{
8 Rozporządzenie Komisji (WE) nr 1155/2009 z dnia 27 listopada 2009r.

9 http://pomorskie.eu/dziedzictwo-kulinarne-pomorskie (dostęp z dnia 11.03.2016)
} 
wadzając kategorię dań i potraw regionalnych, z wykorzystaniem lokalnych, tradycyjnych surowców oraz przyrządzanych według tradycyjnych receptur. Obecnie organizowana jest już XVI edycja konkursu. W pierwszej edycji w 2001 r. nagrodzono łącznie 14 produktów, w tym jeden pochodził z regionu pomorskiego (okrasa kaszubska). Z kolei w 2015 r. przyznano już „Perły” 46 produktom i 10 potrawom w kraju. W grupie nagrodzonych znalazły się 3 produkty z Pomorza: piwo starogdańskie, wianuszek gdański, polędwiczka wędzona kociewska, a także jedna potrawa: karaś w śmietanie z żurawiną. Laureaci konkursu zdobywają rynek i prestiż - poprzez promocję w mediach ich wyroby dotarły m.in. do sieci ekskluzywnych sklepów z tradycyjną żywnością. Warto dodać, iż dorobkiem dotychczas zrealizowanych piętnastu edycji konkursu jest zidentyfikowanie w kraju około 16 tys. regionalnych, tradycyjnych produktów i potraw. Dzięki kolejnym edycjom Konkursu Nasze Kulinarne Dziedzictwo następowała stopniowa konsolidacja środowiska wytwórców produktów regionalnych i tradycyjnych, co zaowocowało powstaniem Polskiej Izby Produktu Regionalnego i Lokalnego.

\section{Podsumowanie}

Współczesna gospodarka wsi staje się patchworkiem zróżnicowanych, lokalnych gospodarek i nie może być dłużej przedstawiana jako zdychotomizowany model tradycyjnej bądź nowoczesnej gospodarki (Marini i Mooney 2006). O możliwościach ich ożywiania decydują różnorodne zasoby lokalne, do których zalicza się także zasoby społeczne i kulturowe, które mogą być wykorzystane w działalności gospodarczej. Te właśnie związki między lokalną gospodarką i lokalnymi zasobami społecznymi i kulturowymi są wykorzystywane do formułowania zróżnicowanych strategii rozwoju lokalnego, stanowiących odpowiedzi na działanie globalnych sił rynku (Podedworna 2011).

Lokalny charakter kultury wsi we wszystkich jej wymiarach - materialnych, społecznych, duchowych - odnosi się przede wszystkim do konkretnego miejsca w przestrzeni i własnych zasobów: przyrodniczych, ludzkich, społecznych, kulturowych, które niegdyś stanowiły i nadal wpływają na jej specyficzną tożsamość. Bardzo często o atrakcyjności i rozmachu działań w sferze kultury nie decydują wyłącznie dostępne środki finansowe czy baza materialna (instytucje i kadry), lecz jakość kapitału ludzkiego i społecznego danej miejscowości. Zatem ważną rolę odgrywa poziom aspiracji animatorów kultury i zaangażowanie mieszkańców.

Istotnym czynnikiem rozwoju wsi województwa pomorskiego jest unikatowe środowisko i walory turystyczne, głównie bliskość Bałtyku oraz występowanie lasów i jezior, umożliwiających rozwój różnych form turystyki i wypoczynku. Pomorze charakteryzuje również różnorodność kulturowa, wynikająca z tożsamości regionalnej i lokalnej. Warto dodać, iż dziedzictwo kulturowe coraz częściej traktowane jest jako ważny czynnik rozwoju lokalnego (sposób na aktywizację gospodarczą, tworzenie nowych miejsc pracy oraz kreowanie pozytywnego wizerunku danego obszaru).

Atrakcyjność krajobrazu województwa pomorskiego jest duża, a to stanowi podstawę rozwoju osadnictwa i gospodarki turystycznej. Dobra jakość środowiska przyrodniczego i zrównoważone wykorzystanie jego zasobów jest podstawą trwałego rozwoju gospodarczego i społecznego regionu. Obszary wiejskie, tereny cenne ze względu na walory przyrodnicze lub obszary peryferyjne są predestynowane do rozwoju w kierunku bio- 
gospodarki. Znaczny udział obszarów prawnie chronionych stanowi na badanym terenie duży potencjał przyrodniczy i krajobrazowy, ale także kulturowy i historyczny. Na ich terenie utworzone są liczne ścieżki ekologiczno-edukacyjne.

Kraina w Kratę, Skansen Wdzydzki, Muzeum Ceramiki i żuławskie domy podcieniowe, to tylko niektóre z zabytków województwa pomorskiego zachwycające swoim wyglądem, bogatą historią i niezwykłą architekturą. Duże natężenie zabytkowej architektury wiejskiej, niespotykane nigdzie indziej w Europie, podkreśla unikalny charakter tego regionu i daje duże możliwości jego wykorzystania w kulturze i turystyce, wzmacniając tym samym jego potencjał. W gminach, w których agroturystyka stała się znaczącym źródłem dochodów, odkrywane są na nowo zapomniane tradycje. Turystyka wiejska, w tym agroturystyka, niewątpliwie dają szansę np. powrotu do tradycji kuchni regionalnej - kaszubskiej i kociewskiej, tradycyjnych zajęć i zabaw, a nawet tradycyjnej zabudowy wiejskiej. Największy potencjał turystyczno-rekreacyjny środowiska przyrodniczego i kulturowego występuje w gminach nadmorskich oraz w centralnej części Pojezierza Kaszubskiego i zachodniej części Borów Tucholskich. Kaszubi, Kociewiacy słowińcy wykształcili odrębną kulturę, obyczaje, język (gwarę ludową), oparte na tradycjach historycznych. Dzięki tej różnorodności pomorskie ośrodki kultury ludowej charakteryzują się obecnie dużą atrakcyjnością turystyczną. Szczególne znaczenie ma jednak kultura kaszubska, która dzięki staraniom różnych instytucji, a także samych mieszkańców Kaszub jest w regionie wciąż „żywa”. Obecnie jej propagatorem są m.in. parki kulturowe i etnograficzne oraz lokalne grupy działania. Natomiast kuchnia kaszubska jest doceniana dzięki potrawom wpisanym na listę produktów tradycyjnych. Lokalne i regionalne produkty żywnościowe cieszą się coraz większym uznaniem i zainteresowaniem konsumentów, co przyczynia się do wzmocnienia poczucia tożsamości regionalnej oraz rozwoju i promocji województwa pomorskiego. Zatem możliwości wykorzystania lokalnych zasobów obszarów wiejskich prezentowanego regionu są duże (m.in. do rozwoju działalności gospodarczej, przy podejmowaniu inicjatyw lokalnych, w celach edukacyjnych).

\section{Literatura}

Choiński A., 2013, Katalog jezior Polski, Wydawnictwo Naukowe UAM, Poznań.

Czapiewska G., 2014, Kapitał społeczno-kulturowy na obszarach wiejskich województwa pomorskiego, [w:] M. Wójcik (red.), Regionalny wymiar przemian polskiej wsi-aspekty społeczne i środowiskowe, Studia Obszarów Wiejskich, 35, s. 121-136.

Czapiewska G., 2016, Organic farming development in Northern Poland in context of environmental conditions an financial suport system, 16th International Multidisciplinary Scientific GeoConference SGEM 2016, Albena, Bułgaria (w druku)

Ditrich B., Słubik D. (red.), 1998, Kuchnia Pomorska: 241 przepisów, ODR, Gdańsk.

Korenik S., 1999, Rozwój regionu ekonomicznego na przykładzie Dolnego Ślq̨ska, Wydawnictwo Akademii Ekonomicznej, Wrocław.

Latoszek M. (red.), 1990, Kaszubi: monografia socjologiczna, Towarzystwo Naukowe Organizacji i Kierownictwa, Rzeszów.

Marini B., Mooney P.H., 2006, Rural economies, [w:] P. Cloke, T. Marsden, P. Mooney (red.), Handbook of Rural Studies, Londyn, Sage Publications, s. 91-103.

Mordawski J., 1999, Geografia współczesnych Kaszub, Instytut Kaszubski, Gdańsk. 
Niemiec W., 2004, O tim jak przóde lat Kaszëbi warzële, Wydawnictwo BWN Studio, Rumia.

Olbracht-Prondzyński C., 2007, Kaszubi dzisiaj: kultura, język, tożsamość, Instytut Kaszubski, Gdańsk.

Podedworna H. 2011, Urynkowienie zasobów wsi w Polsce, Uniwersyteckie Czasopismo Socjologiczne, 5, s. 4-21.

Przemyst i działalność innowacyjna w województwie pomorskim w 2014 roku, 2015, Opracowania sygnalne, Urząd Statystyczny w Gdańsku, Gdańsk.

Raport statystyczny - twórcy ludowi i ginqce zawody (wg bazy danych STL za 2013 rok), www.cbos. pl (dostęp z dnia 11.05.2015)

Spis rzeczy ważnych. Katalog zasobów lokalnych regionu Gór Świętokrzyskich, 2012, Ośrodek Promowania Przedsiębiorczości, Sandomierz.

Warczak M., 2015, Endogeniczne i egzogeniczne czynniki rozwoju gospodarczego z perspektywy finansów gminy, Współczesna Gospodarka, 4, s. 111-122.

\section{Summary}

This article presents issues related to the role and importance of local resources for development of rural areas in Pomerania (Pomorskie Voivodeship). The spatial scope of the research encompasses the Pomorskie Voivodeship, occupying a total area of 18310,34 $\mathrm{km}^{2}$, which represents 5,9\% of the country. This article comprises analysis of selected local cultural and natural village resources in the Pomeranian region. The paper presents local resources of the region, which are particularly associated with cultural, social and natural heritage of Kashubians. The aim of the study was an attempt to assess the impact of local resources on socio-economic development of rural areas in Pomerania. The first part presents natural, landscape and cultural diversity of examined area, while the second concerns richness and culinary specificity of Pomerania region, local and traditional products. An important factor in the development of the Pomeranian village is a unique environment and tourist attractions, mainly the proximity to the Baltic Sea and the presence of lakes and forests, enabling the development of various forms of tourism and recreation. Pomerania is also characterized by cultural diversity, resulting from local and regional identity. It is worth noting that cultural heritage is increasingly regarded as an important factor for local development (by fostering economic activation, creating new jobs and positive image of the area). Kashubian traditions are promoted by i.a. cultural and ethnographic parks or local action groups. Regional Kashubian dishes are to a greater extent appreciated and included on the list of traditional products. Local and regional food products are becoming increasingly recognized by consumers, which contributes to the strengthening of regional identity and promoting the Pomorskie Voivodeship. 
http://rcin.org.pl 